Revista Brasileira de Higiene e Sanidade Animal

Brazilian Journal of Hygiene and Animal Sanity

\title{
Nutritional approach of pregnant queens and neonate cats: A review
}

\section{Francisco Antônio Félix Xavier Júnior', Karen Denise da Silva Macambira², Steffi Lima Araujo ${ }^{3}$, Victor Manuel Lacerda Freitas ${ }^{4}$, Glayciane Bezerra de Morais ${ }^{5}$, Glícia Meneses Costa ${ }^{6}$, João Alison de Moraes Silveira ${ }^{7}$, Janaina Serra Azul Monteiro Evangelista $^{8}$}

1. Faculdade de Veterinária, Universidade Estadual do Ceará, UECE - Médico Veterinário. Email: juniorberith@gmail.com

2. Faculdade de Veterinária, Universidade Estadual do Ceará, UECE - Médica Veterinária. Email: karenmacambira@veterinaria.med.br

3. Faculdade de Veterinária, Universidade Estadual do Ceará, UECE - Graduanda. E-mail: steffi.araujo@hotmail.com

4. Faculdade de Veterinária, Universidade Estadual do Ceará, UECE - Graduando. E-mail: victorlacerda@veterinario.med.br

5. Programa de Pós-graduação em Ciências Veterinárias, Universidade Estadual do Ceará, UECE - Médica Veterinária. E-mail: glaycianebm@yahoo.com.br

6. Programa de Pós-graduação em Ciências Veterinárias, Universidade Estadual do Ceará,

UECE - Médica Veterinária. E-mail: gliciamcosta@hotmail.com

7. Departamento de Fisiologia e Farmacologia, Universidade Federal do Ceará, UFC - Médico Veterinário. E-mail: silveira.jam@gmail.com

8. Laboratório de Morfologia Experimental Comparada do Programa de Pós-graduação em Ciências Veterinárias, Universidade Estadual do Ceará, UECE - Médica Veterinária. E-mail: janainaserrazul@gmail.com

\begin{abstract}
The knowledge about feline nutrition and its effects on the animal's health is a reality in veterinary medicine. It has had progressively more investments in this area, since the dietary management can prevent the development of certain diseases affecting many organ systems and assists in the treatment of certain gastrointestinal diseases and others. The nutrition of cats has its defined importance because the feline diet has its differences according to the physiological stage of the animal and its nutritional requirements. It is understood that the nutritional variations are more evident between different physiological stages than even among different species at the same physiological stage. There are many differences in nutritional management in cats when compared to dogs. Since the concentration of proteins and lipids up to the amounts of vitamins and minerals that are necessary. To understand the nutritional needs of the feline species is essential to establish a balanced and healthy diet that can provide to the animal a higher life expectancy associated with a great quality of life. The aim of this study is to conduct a literature review on the most important aspects of nutrition in domestic cats, emphasizing the different physiological stages and their requirements for an adequate management of the dietary needs of these animals.
\end{abstract}

Keywords: Small animal nutrition, Feline, Neonate.

Autor para correspondencia. E.mail:*juniorberith@ gmail.com 
Recebido em 12.5.2016. Aceito em 28.12.2016 http://dx.doi.org/10.5935/1981-2965.20160065

\section{Introduction}

The need of an adequate feed that contain nutrients that provide energy is basis of animal nutrition study (WOLFARTH et al., 2011). Gestation is a phase of crucial importance to the neonate (Domingos et al., 2008), and this period bitches and queens with low mass could not be able to ingest sufficient food to attend the puppies and their own needs. It causes production of light puppies and high mortality level. Although, obese queens tend to produce large fetus and have predisposition for queening complication (PET, [S.d]). In this period, nutritional mistakes, inadequate treatments and any disease can determinate embryo reabsorption, abortion or perinatal death (DOMINGOS et al., 2008).

In queens, differently than bitches, the weight gain is linear since conception until queening, occurring increase of $40 \%$ at anterior weight (It means $900-1200 \mathrm{~g}$ to a litter of medium size). At queening time, the queen loses $40 \%$ of gained weight during gestation, others $60 \%$ are to generate and maintain lactation (MONTEIRO, 2008). The correct knowledge of animal life phases helps to determine the food management adequate to each animal phases searching a good health condition and quality of life (BORDIN, [s.d]). In this study, we aimed to conduct a literature review about food management care in pregnant feline and kittens, highlighting their importance.

\section{Feline Nutrition}

Some archaeological finds show that domestic cats are direct descendants of smaller felines, and not from big felines and great hunters. It demonstrates that actual felines are supposed to be fed more times daily (BORDIN, [s.d]). Cats have a set of particularities that distinguish them from others carnivores animals, such as dogs. Those differences reflects naturally predatory lifestyle of cats and their ability to live with a diet derived entirely from animals (DUTRA et al., 2011; WITZEL et al., 2012).

Determining daily nutritional needs of cats are simple to be formulated, once the calculation is done based on body weight, thus giving Basal Energy Expenditure $(G E B)$ in Kcal/day (Table 1) (SOUZA, [S.d]). 


\begin{tabular}{|l|l|}
\hline \multicolumn{2}{|l|}{ Table 1: Calculation of Basal Energy Expenditure (GEB) per day in cats } \\
\hline Cat with body weight less than $2 \mathrm{~kg}$ & $\begin{array}{l}\mathrm{GEB}=70 \mathrm{x} \text { (body weight in } \mathrm{kg}) \times 0,75 \\
(\mathrm{Kcal} / \mathrm{day})\end{array}$ \\
\hline $\begin{array}{l}\text { Cat with body weight equal or higher than } 2 \\
\mathrm{~kg}\end{array}$ & $\begin{array}{l}\mathrm{GEB}=30 \mathrm{x} \text { (body weight in } \mathrm{kg})+70 \\
\text { (Kcal/day) }\end{array}$ \\
\hline
\end{tabular}

It is well accepted that protein levels need to be higher for growth, reproduction, and lactation (Laflamme, 2013) Cats have a higher minimum protein requirement in their feed than dogs (FIORAVANTI, 2012). Food specialization does not allow the cat to obtain adequate levels of some essential nutrients to ensure a healthy life, for example amino acids such as taurine and arginine, vitamin A, niacin (B vitamins) and arachidonic acid, which that must be necessarily present in their diet (ANUSZ, 2006).

In the 1980s, the major of Brazilian pets were still fed with food waste of their owners. There were just a few pet food industries in the country (BORGES et al, [S.d]). The production of complete feeding stuffs for dogs and cats grew 7\% in 2010, according just above two millions tones, taking into account that $44 \%$ Brazilian households have company animals.

The dog and cat food are classified in combat, economic, standard, premium and super premium, according to raw material used in manufacturing (WOLFARTH et al., 2011).

\section{Pregnancy in Cats}

The major part of feline species have ovulation induced by copula. The neuroendocrine reflex triggers ovulation in cats is produced by stimulation of vaginal receptors through penile spines during the mating in which a nerve impulse is created and induce hypothalamus to release the gonadotropin-releasing hormone $(\mathrm{GnRH})$. This releasing hormone is responsible for the release of follicle-stimulating hormone (FSH) and luteinizing hormone (LH) from the anterior pituitary. The LH increase initiates about 15 minutes after copula, the peak occurs in 2 hours returning to basal level in 8 hours. Ovulation occurs 24 to 50 hours after copulation (MONTEIRO, 2008).

Pregnancy lenght in queens, from date of first or last mating until initiation of parturition, average 65,6 days, with a range of 53-74 days (KUSTRITZ, 2006). Gestation diagnosis is achieved through 
physical examination (abdominal palpation on 3 weeks of gestation, kittens can be felt), radiography exam (allowing detect gestation from the 21 st day) or abdominal ultrasound (from the 20th day) (MOREIRA et al., 2005). It has been observed that successful gestation and lactation in companion animals are results of factors as creating management, maintaining a healthy environment and providing consistent and adequate diet at long term (CASE et al., 2011).

\section{Pregnant Queens}

The phases aimed to reproduction of cats are stages that require particular feed attention because the female needs to have ability of developing and maintaining her offspring and have food and environment conditions for lactation (BORDIN, [S.d]). Pregnant queens as well as humans, gain weight gradually throughout pregnancy (Fioravanti, 2012) due to the presence of the fetus, the placenta, the associated tissues and the body reserves necessary for lactation (WICHERT et al, 2009).

Lack of proper nutrition during pregnancy can result a decrease in birth weight and an increase in neonatal mortality. On the other hand, an overweight condition can lead to the development of large fetus and dystocia (CASE et al., 2011). The need for water increases during pregnancy because of expansion of the extracellular fluid compartment, maternal and fetal tissue and lactation. Thus, drinking water should be available all the time (STURION et al, [S.d]).

At least two weeks before breeding should be provided high quality food with easy digestibility and appropriate for pregnancy and lactation. Changing the diet at the beginning of the reproduction allows the queen be adjusted to the new food and avoids the need to change abruptly diets during pregnancy or lactation (CASE et al., 2011).

In the second week of pregnancy, queens have an increase of food intake and energy requirements are gradually raised (Fioravanti, 2012) reaching, in the ninth week, a consumption of $25 \%$ to $50 \%$ higher than the maintenance. Cats adapt well to food offered at will and that is the most suitable system for the reproductive period (PREMIER, [S.d]). The concern is keeping female in good physical condition, since fetal development in these early stages does not seem to require great nutritional demands from the mother (STURION et al, [S.d]). Calculating the metabolizable energy (ME) using the Atwater factors modified needs a similar requirement of 90 $\mathrm{kcal} / \mathrm{kg}$ BW (body weight), and it recommends energy requirement of pregnant queens in about $140 \mathrm{kcalEM} / \mathrm{kg}$ BW (WICHERT et al, 2009).

Breeders usually supplement the breeding dogs and cats with calcium, 
vitamin D and foods rich in calcium during pregnancy and lactation. However, from a nutritional point of view, calcium supplements, vitamin $\mathrm{D}$, and any other nutrients is not necessary, and even is contraindicated if a balanced diet is used and it can cause calcification, fetal deformities and puerperal tetany, tremors, seizures, fever and others signals (MUNDO pet, [S.d.]).

At starting the fetus development, especially in the last third of pregnancy, there is a gradual reduction in the abdominal space available for expansion of the digestive tract after meals (PREMIER, [S.d]). It is advisable to provide several meals a day, plus increased energy and nutrient density food (PET WORLD, [S.d.]). Fats release over twice the amount of calories when compared to carbohydrate representing a major source of energy. As a rule, the ideal would be to increase all the nutrients of the daily diet in approximately 25 to $35 \%$ above recommended levels, for maintenance to ensure a normal weight at birth, it promotes a normal growth rate of the kittens (STURION et al., [S.d.]).

The fatty acid docosahexaenoic n-3 (DHA) is very important for breeding queens and their fetus, also essential for neurological development and normal retina in puppies and kittens. Adult animals have a limited capacity to synthesize DHA from alpha-linolenic acid, the best way to provide DHA to the fetus is through the mother's diet enrichment during pregnancy and lactation. Omega 3 and omega 6 should be supplied in the diet; the ideal ratio is 5:01 and 10:01, respectively. Those are important because the essential fatty acid of a female (EFA) is negatively influenced by the physiological stress of pregnancy and lactation (CASE et al., 2011).

Piechota et al in 1995 determined in a study the cats nitrogen needs during pregnancy and lactation. It demonstrated that the requirement of protein during pregnancy is not more than $200 \mathrm{~g}$ protein / $\mathrm{kg}$ diet and during lactation is between 250 and $300 \mathrm{~g}$ protein / $\mathrm{kg}$ diet containing $250 \mathrm{~g}$ fat / $\mathrm{kg}$ diet. The dietary protein requirements increase from $40 \%$ to $70 \%$ above maintenance (STURION et al., [S.d.]).

In summary, some basic factors are recommended during pregnancy: high digestibility and specific food for the phase, energy values controlled until the fifth week, small servings - in the final third of gestation, enhance the nutritional concept by physiological stage, note weight gain of females $-20 \%$ on average (BORDIN, [S.d.]).

\section{Colostrum Importance in the Health of} Kittens

Many of the causes of premature death in kittens are related to poor nutrition in early life. Some studies have shown that 
up to $30 \%$ of kittens may die before weaning, when considering the time until puberty and this rate can be higher (DOMINGOS et al., 2008). It is important to define the neonatal period, which has a variety of definitions according to the opinion of different researchers, so, the nutritional needs at this stage are met properly. In general, it is accepted that the neonatal period may comprise from birth to the first ten days of life (PRATS \& PRATS, 2005). Moreover, Prats (2005) has held that the period between the 10th and 20th day is the transition period, when there is a clear distinction with the appearance of incisors and deciduous prey.

The physiological functions of the puppies are very different from adults, for example, liver and kidney function that are not fully developed, also thermoregulatory, cardiopulmonary, gastrointestinal and immunologic functions should be considered in a context where is attempted to evaluate the nutritional needs of these animals (CARDOSO, 2000). In addition, a dramatic change of the uterine environment for the external environment has a significant influence on the kittens body because of the quick adaptations of the circulatory and respiratory system and the immunological challenges that the animal should overcome. Therefore, the consumption of colostrum in the first hours of life of the kitten is critical to the proper development of the organism (DOMINGOS et al., 2008).

It is important to consider when there is the need for a cat to have cesarean delivery. That is because of the use of an anesthetic protocol that takes into account the ability of anesthetics surpass placental lye. Some drugs can cause fetal depression and decreasing the litter viability due to less efficient use of colostrum after birth (GREENE, 1995).

Some care is essential after the birth of the kittens. It is important to provide a supplement with all the nutrients in quantity and quality guaranteed in the first hours of life. If the mother is healthy and has a good milk production, the nutritional needs of the kittens are all met during the first three weeks of life (HOSKINS, 1997). Soon after the birth of kittens, the mother produces a differentiated milk known as colostrum, it is essential to provide passive immunity through the complete absorption of immunoglobulins by the gastrointestinal mucosa of the kittens. Some research has shown that Kittens may have a shorter window for transferring bioactive components such as immunoglobulins and growth factors compared to other species, ranging from three to six hours, stopping to absorb between 16 and 24 hours after birth (CASAL et al., 1996). In addition, colostrum provides nutrients and increments the circulatory volume of 
puppies. This is essential for the development of physiological functions and correct functioning of the cardiovascular system (CASE et al., 1998).

The colostrum composition changes during the first three days after birth until it becomes milk. Colostrum has a lower concentration of protein, fat and total sodium when compared to milk (Table 2), but colostrum has a higher concentration of iron $\left(\mathrm{Fe}^{3+}\right)$, reducing this difference over the days (HOSKINS, 1997).

When the kittens do not have access to breast milk because of the mother's death or problems regarding the production of colostrum and milk, for example, agalactia, hypogalactia or presence of severe mastitis, which does not allow breastfeeding, it is necessary provision of a suitable substitute for the breastmilk (COFFMAN, 2001). An adoptive mother is not always the easiest solution, the best alternative would be a milk substitute that has a composition at least like the cat milk. Bovine milk as a substitute can cause various digestive disorders to the kittens, including diarrhea, negatively affecting the puppy's growth and raise the development of opportunistic infections (MOORE, 2005). In the market there is some replacement options for breast milk feline, however, the use of these commercial formulations is still not widespread. There are some homemade recipes that can be used to produce a more suitable substitute for the needs of a kitten (PRATS \& PRATS, 2005).

To offer the substitute of the breastmilk for the animal, there are several strategies that can be used, for example, bottles, syringes, eyedropper and even gastric and / or nasogastric probes. After each feeding, it should be done a massage over the abdomen to stimulate urination and defecation (MOORE, 2005). The feeding through bottle would be ideal since it stimulates the sucking reflex and push the kitten to eat; it decreases the risk of false way that may happen with other methods mentioned above (SORRIBAS, 2004). The interval between each feeding can vary according to age of the puppy until weaning, and in general, the feeding can be at intervals of 3 to 3 hours (PRATS \& PRATS, 2005).

\section{Prebiotics and Probiotics as Supplements in the Diet}

Sterile at birth, the gastrointestinal tract of kittens are colonized within a few hours by different species of microorganisms, including bacteria, fungi, protozoa and even some virus. This well controlled colonization involves a variety of organisms find their own niche along the digestive tract, resulting in different groups of microorganisms colonizing various locations in the intestinal tract (GRECO, 2014). During the process of colonization, the bacteria are arranged in a state of 
balance between beneficial and harmful conditions, keeping the health of the animal. It is widespread the importance of the intestinal microbiota in the animal's health, there is a significant interest in the manipulation of these microorganisms. Studies have shown that oligosaccharides which are not digested by the animal, in general, they are used as prebiotic fibers and has been used to modulate bacterial growth by increasing the number of the good bacteria (GRECO, 2014).

The prebiotic fibers has demonstrated many benefits related to the stimulation of the immune system, anticancer effects, antidiarrheal effects and increased absorption of nutrients. Inulin, fructo-oligosaccharide, mono-oligosaccharides and beet pulp are some examples of prebiotic fibers that can be offered for the kitten (ADOGONY et al., 2007).

Probiotics have been used in both dogs and cats since 1985 for health maintenance and restoration of intestinal microflora in animals that developed a disorder caused by diet, stress and therapies with antibiotics (GRECO, 2014). Kittens can be susceptible to develop episodes of diarrhea, particularly in weaning time or if insufficient volume of colostrum has been ingested. In both cases, probiotics administration as Enterococcus faecium, repopulate the gut with beneficial bacteria for 14 days, allowing the repair and stabilization of the intestinal microbiota (BENYACOUB et al., 2003). Many probiotics are available in the market, but many of them have not gone through rigorous clinical studies to prove its effectiveness. The manufacturer should be able to provide documentation as the stability of the probiotic and the ability to survive in the intestine for at least 14 days (GRECO, 2014).

Interestingly, a decrease in the occurrence of clinical signs of herpes virus during stress was noted when cats were supplemented with probiotics (LAPPIN et al., 2009). This improvement of the immune system in kittens has important implications for a better health of the pets as well as a better immune response to vaccination.

\section{Energy Requirements of Cats in Growth} Phase

It is understood that the nutritional variations are more evident between different physiological stages than even among different species at the same physiological stage. During the growth phase, one of the most critical periods related to nutrition, it is important to know the cat's energy requirement in order to have a good performance, avoiding underconsumption or overconsumption and the consequences that this can bring to the health of the feline (NRC, 2006).

According to the Animal Nutrition Council of the National Research Council 
(NRC) in 2006, newborn cats have an energy requirement of approximately 20 25 kcal per $100 \mathrm{~g}$ of body weight. Kittens are born with the weight of approximately $100 \mathrm{~g}$, weaning next two months old with about $500 \mathrm{~g}$. The adult weight is reached between 8 - 12 months, with a weight ranging from 4 to $7 \mathrm{~kg}$. Knowing this, the kittens have specific nutritional needs for proper growth, and these needs are estimated by the factorial method. It is estimated 4,8kcal EM and 0.40g PB per gramme of gain. The energy requirement of kittens after weaning is 3.0 to 4.0 times more than an adult animal $(70 \mathrm{kcal} / \mathrm{kg}$ of body weight), from 1.75 to 2.0 times higher after 5 months and from 1.25 to 15 times higher with 7-8 months, which are already reaching the weight close to that of an adult. To simplify the daily needs of metabolizable energy for growth Kitten after weaning, the following formula can be used:

$\mathrm{EM}(\mathrm{Kcal})=100 \times \mathrm{PCa} 0,67 \times[\mathrm{e}(-0,189 \mathrm{p})$ $-0,66]$

Where:

$\mathrm{p}=\mathrm{PCa} / \mathrm{PCm}$

$\mathrm{PCa}=$ current body weight on the valuation date $(\mathrm{Kg})$

$\mathrm{PCm}=$ expected body weight when adult $(\mathrm{Kg})$

$\mathrm{e}=\log \approx 2.718$

The Table 2 shows the most current values of the percentages of nutrients required by cats in the growth phase and in adulthood for maintenance. With this data it is possible to compare the tabulated values in feed bags with the values recommended by the American Association of Official Food Control Officials (AAFCO).

\begin{tabular}{|l|l|}
\hline \multicolumn{2}{|l|}{ Table 2: Cat's milk composition } \\
\hline Constituents & Cat \\
\hline Total Protein (\%) & 9,5 \\
\hline Lactose (\%) & 10,0 \\
\hline Total Fat (\%) & 6,8 \\
\hline Totais Sólids (\%) & 23,0 \\
\hline Energy Kcal/100mL & 142 \\
\hline
\end{tabular}

Source: Modificated from Sorribas 


\section{Conclusion}

Feline nutrition has developed and progressively specialized in recent years. It meets the requirements that the market has been demanding. Cats are different in several aspects of its life, especially with regard to food. This study has given us a better understanding in relation to an understudied subject of difficult to access, showing relevant for both academic and

\section{References}

1.AAFCO. AAFCO Methods for Substanting Nutritional Adequacy of Dog and Cat Foods, 2014.

2. ADOGONY, V.; RESPONDEK, F.; BIOURGE, V. Effects of dietary scFOS on immunoglobulins in colostrum and milk of bitches. Journal Animal Physiology Animal Nutrition, 2007, p. 91 - 169.

3. ANUSZ, T.F. Deficiências Nutricionais e de Manejo em um Gatil e suas Consequências. 2006. 42f. Trabalho de Conclusão de Curso (Pós- Graduação Lato Sensu em Clínica Cirúrgica em Pequenos Animais), Universidade Castelo Branco, Rio de Janeiro, 2006.

4. BENYACOUB, J.; CZARNECKIMAULDEN, G.L.; CAVADINI, C. Supplementation of food with Enterococcus faecium (SF68) stimulates immune functions in young dogs. Journal Nutrion, 2003, p. $1158-1162$.

5. BORDIN, R.A. Conceitos de Alimentação ao Longo da vida de Cães e Gatos. [S.d.].

6. BORGES, F.M.O; SALGARELLO, R.M; GURIAN, T.M. Recentes Avanços Na Nutrição de Cães e Gatos. p. 1-32, S.d. professional veterinarians. Feeding and nutrition are very important for a healthy pregnancy in animals with purpose of providing adequately essential nutrients and energy needed to know the daily requirements of the animal in each of the stages of life. The owner must keep eye on food composition ingested by the animal because the development of diseases may be related to the animal feed quality.

7. CARDOSO, R.C. Neonatologia canina. In: I Ciclo de Atualização em Ciências Veterinárias, Fortaleza-Ce, 2000. p. $49-52$.

8. CASAL, M.L.; JEZYK, P.F.; GIGER, U. Transfer of colostral antibodies from queens to their kittens. American Journal Veterinary Research, p. 1653 - 1658, 1996.

9. CASE, L.P; DARISTOTLE, L.; HAYEK, M.G; RAASCH, M.F. Canine and Feline Nutrition: a resource for companion animal professionals. $3 \mathrm{ed}$. Elsevier, 2011.

10. CASE, L.P.; CAREY, D.P.; HIRAKAWA, D.A. Cuidados nutricionais dos filhotes recém-nascidos. In: CASE, L.P.; CAREY, D.P.; HIRAKAWA, D.A. Nutrição canina e felina - manual para profissionais. Lisboa: Harcourt Brace, 1998. p. $1997-207$.

11. COFFMAN, M. Care and feeding of the lactating bitch, canine reproduction and neonatal health. Tufts Animal Expo, 2001, p. $4-8$.

12. DOMINGOS, T.C.S; ROCHA, A.A; CUNHA, I.C.N. Cuidados básicos com a gestante e o neonato canino e felino: revisão de literatura. Jornal Brasileiro de Ciência Animal, v. 1, p. 94-120, 2008. 
13. DUTRA, L.S; ARALDI, D.F; CENTENARO, V.B. Nutrição De Gatos. In: Seminário Interinstitucional de Ensino, Pesquisa e Extenção, n. XVI, 2011.

14. FIORAVANTI, M.C.S. Nutrição dos Cães e Gatos. Apresentação em Power Point, p. 1-16, 2012.

15. GREECO, D.S. Pediatric Nutrition. Veterinary Clinics of North America: Small Animal Practice, March 2014, p. 265 - 273

16. GREENE, S.A. Anesthetic considerations for surgery of the reproductive system. In: Seminars in Veterinary medicine and surgery (small animal), 1995. p. $2-7$.

17. HOSKINS, J.D. Pediatria Veterinária: Cães e gatos do nascimento aos seis meses. Rio de Janeiro: Interlivros, 1997.

18. KUSTRITZ, M.V.R. Clinical management of pregnancy in cats.

Theriogenology, v. 66, p. 145-150, 2006.

19. LAPPIN, M.R.; VEIR, J.K.; SATYARAJ, E. Pilot study to evaluate the effect of oral supplementation of Enterococcus faecium SF68 on cats with latent feline herpes virus. Journal Feline Medicine and Surgery, 2009, p. 650.

20. MONTEIRO, C.L.B. Avaliação da Gestação em Gatas Domésticas: Parâmetros Ultrassonográficos, Reprodutivos e Perfil Biométrico Dos Filhotes Ao Nascimento. 2008. 90f. (Dissertação de Mestrado em Ciências Veterinárias) - Faculdade de Veterinária, Universidade Estadual do Ceará, Fortaleza, 2008.

21. MOORE, P.H. Care and management of neonate. MEDVEP - Revista Científica de Medicina Veterinária, 2005.

22. MOREIRA, F.L. Fisiologia do ciclo reprodutivo da gata. Cães e Mascotes, p. 6062, 2005. Mundo Pet. Nutrição de fêmeas reprodutoras. [S.d.]. Disponível em < http://www.sitemundopet.com.br>. Acesso em: 03 março de 2016.

23. NRC. Nutrient Requirements of Dogs and Cats. Washington. 2006.
24. PRATS, A. \& PRATS, A. O exame clínico do paciente pediátrico. In: A. PRATS. Neonatologia e pediatria: canina e felina. São Caetano do Sul - SP: Interbook editora, 2005. p $96-113$.

25. PIECHOTA, T.R.; ROGERS, Q.R; MORRIS, J.G. Nitrogen Requeriment of Cats during Gestation and Lactation. Nutrition Research, v. 15, n. 10, p. 1535-1546, 1995.

26. PREMIER. Nutrição de cadelas e gatas gestantes. p. 1-4, [S.d.]. Disponível em < www.premierpet.com.br>. Acesso em: 05 março de 2016.

27. SORRIBAS, C.E. Cuidados com o neonato canino e felino. MEDVEP - Revista Cia de Medicina Veterinária, 2004.

28. SOUZA, H.J.M. Técnicas de alimentação enteral em gatos (cálculos das calorias diárias). Associação Argentina de Medicina Felina, n. Quadro 2, p. 2-5, [S.d.].

29. STURION, D.J; SALIBA, R.; NOGUEIRA, M.C; MARTINS, E.L.; NETO, A.L.F. Manejo nutricional em animais gestantes - revisão de literatura. [S.d.].

30. WICHERT, B.; SCHADE, L.; GEBERT, S. Energy and protein needs of cats for maintenance, gestation and lactation. Journal of Feline Medicine and Surgery, v. 11, n. 10, p. 808-815, 2009.

31. WITZEL, A.L.; BARTGES, J.; KIRK, C.; HAMPER, B. Nutrition for the Normal Cat. The Cat, p. 243, 2012.

32. WOLFARTH, D.; JOHANN, M.; ARALDI, D. A importância de uma dieta de qualidade na alimentação de cães e gatos. In: Seminário Interinstitucional de Ensino, Pesquisa e Extenção, n. XVI, 2011. 